\title{
Double Colonization: A Postcolonial Feminist Study Of Sia Figiel's Where We Once Belonged
}

\author{
Shene Mohammad Ahmed \\ shene.ahmed@univsul.edu.iq \\ School of Basic Education/ English Department, University of Sulimani
}

\begin{abstract}
The article deals with analyzing female characters in the WHERE WE ONCE BELONGED by Sia Figiel. The novel is important for students who study postcolonialism and feminism as it gives an insight for gender and race issues. The aim of this article is to show how females in a male-dominated societies are persecuted. Furthermore, females are regarded as inferior according to Edward Said's theory of Orientalism. The Samoan culture was once colonized by the British. Therefore, the legacy of colonialism and its effects remains there, even after the national independence. It first gives some clarifications about the publishing of the novel and the writer. Then, it comes to the discussion about the colonialism in the novels with its connections to the main characters and how the colonizers were, and also how it affected their lives. In the next part, it explains double colonization. It talks about how almost all of the postcolonial writings were occupied by how women were muted. Then, it recalls how the female characters were suppressed and oppressed by the males and the English dominant power. It shows how they were double-colonized, not having even the freedom to show it.
\end{abstract}

Keywords: Colonialism, Postcolonial Feminism, Double Colonization, Orientalism

\section{Article Info}

Received date: 1 November 2018 Revised date: 23 November 2018 Accepted date: 22 Januari 2019

\section{INTRODUCTION}

It is essential to know the definition of feminism and postcolonial feminism. The long history of feminism goes back to the late $60 \mathrm{~s}$ and early $70 \mathrm{~s}$ of the $20^{\text {th }}$ century in the West. Feminism emerged as a reaction against the inhuman and unequal remarks against woman. The western feminism tried to find the reason behind classifying women as second class citizens and mostly oppressed. Since that time feminist tried to examine issues of sex, gender, and notably language in literary texts. Feminism in multi-cultural communities took different shapes. For instance in Indian culture, the four types of feminism exists such as First world, Second world, Third world, and forth world. Feminism in the former colonies and after the national independence took a new form which is postcolonial feminism. The feminists in these colonies felt that they should represent themselves as well as they experienced colonization and affected by it.

Postcolonial feminism emerged from the gendered history of colonialism. Basically, because the colonial power always imposed its Western norms on the colonized countries. This colonial oppression made the colonized people to appreciate the pre-colonial culture and fight for it after the national independence. Likewise, Postcolonial feminists have argued that oppression relating to the colonial experience, particularly racial, class, and ethnic oppression, has marginalized women in postcolonial societies. Moreover, they believe that gender differences are the main force behind patriarchy. They also reject the portrayal of non-Western women as voiceless and passive victims. They object to the representation of the Western women as modern, educated and empowered (Bulbeck, 1998, P. 333).

One of the pivotal concepts to identify the status of people and particularly women in the colonized countries is the concept of double colonization. Women in the colonized countries are doubly colonized, once by the imperial power and by the male-dominated society. Depending on Edward Said's theory of orientalism and focusing on the concept of double colonization, subalternity, and marginalization of women this study is discussed. The term double colonization is coined in the mid1980s, and usually identified with "Holst Petersen and Rutherford's A Double Colonization: Colonial 
and Post-Colonial Women's Writing published in 1985" (Ashcraft et al.,1989). Furthermore, double colonization examines how women are subjected to colonial power and male-domination. Thus both the imperial power and patriarchy control women in the colonized countries. The origin of the word "patriarchy" is from Greek; Patria which means father and arché means rule, and thus patriarchy means rule of the father. In general patriarchy means that men dominate the society through their position either politically or religiously. The purpose behind this study is to show how women in former colonies are controlled twice.

\section{METHOD}

This novel is analyzed according to Said's theory of orientalism, in which he categorized the world into self or the occident which stands for the West and the orient or other stands for the East, the occident is the center, while the orient is the margins or peripheries. This "self" and "other" mentality that many colonizers take with them into a new country. He further argues "such ... geographical sectors as "Orient" and "Occident" are man-made. Therefore as much as the West itself, the Orient is an idea that has a history and a tradition of thought, imagery and vocabulary that have given it reality and presence in and for the West." (Said, 1967, P. 5). Said points out the orientalism is not merely related to work of European imagination, rather it is mostly related to power, domination, and authority. In this regard orientalism is not only about misrepresentation of the Occident about the orient it rather "created body of theory and practice in which, for many generations, there has been a considerable material investment," (Said,1967,P. 6) .

Said's theory of orientalism in relation to the concept of double colonization, the occident stands for men and the orient stands for women, because in male dominated societies, women are doubly marginalized. Men are superior and women are inferior. Thus women are doubly colonized; once they represent the other for the imperial power, and the second time they also represent other for their own husbands, fathers, and the society. In this respect, the imperial power and patriarchy have the same role in dominating their control over the female as a colonial subject. Likewise, feminist theory also proved that women are marginalized by patriarchal society and it also parallels itself with the development of postcolonial theory. Basically, marginalization is defined as a deviation from the norms.

Orientalism as "A Western style for dominating, restructuring, and having authority over the Orient" (Said,1967,P. 3). Orientalism deals with the representation of the self and the other; in the two novels female characters represent the orient or the other ; the passive and silent characters who are controlled by the male characters in which they represent the occident and the self. Moreover, this study argues that women are persecuted in the colonial societies twice. Accordingly, female characters represent the other twice; the first time, they represent the other for the colonial power and secondly, they represent the other for the patriarchal power. In Where We Once Belonged, Sinva and Lili are victims to the patriarchy and colonization.

\section{DISCUSSION}

Historically, Stevenson in his book A Footnote to History: Eight Years of Trouble in Samoa (1892), denotes how Samoa was colonized by the German, American and English colonizers. The capital city is Apia , Samoa consists of two main islands Savai'i and Upolu with four smaller islands surrounding the landmasses. Where We Once Belonged is a novel which came into the Pacific literature in 1990 by the renowned novelist Sia Figiel. She has Polish American blood from her father and Samoan on her mother's side (Brwon, 2015). According to the Pasifika Press, This was her first ever novel which won her the Commonwealth Prestigious Writer's prize for the best first book in the South East Asia and South Pacific regions in 1997. Moreover, Sia Figiel's novel is the story of a young Samoan girl, Alofa, the protagonist, as she grows up in Malefou with her family. It portrays many coming-ofage stories in the town and also provides numerous instances of the effects of colonialism on the individuals and the culture of Samoa. There are two themes, being masterfully demonstrated in the novel and with Figiel doing an amazing job to constantly put the reader on alert about them, which are: firstly, fighting against colonialism can sometimes cause harsh counteraction and secondly growing up in an impaired family manifests itself as a challenging task. According to Kaya press (1999, P. 2); Figiel interweaves the two themes in such a way that excites the reader to stick with the poem-like style of writing from word to word. 
What is really evident in this novel that all the villagers are strongly influenced by Western colonialism and are completely unaware of it. They have favored a new culture over theirs and integrated to it as the colonial systems always require. Accordingly, the author shows many instances of this matter in the novel. The natives of the village are religious people always attending the masses, basing their lives on a God as they were told.

Edward Said in his famous book "Orientalism" defines orientalism as "A Western style for dominating, restructuring, and having authority over the Orient." (Said, 1967,P. 3). Thus, colonization is not always the physical presence of a colonizer in a certain place but rather a force rooting into the various aspects of life, culture and society while "restructuring" it, also maintaining authority over it through the new, re-defined norms in the "Orient" or "the other" or the "colonized" that is; leaving footprints and tremendous influence on the colonized. Bill (Ashcroft and et al.,1989) state in The Empire Writes Back that "In fact, colonization was not only a power control but it was a cultural control by the colonizer in which still colonized people tied to and from which they suffered". Figiel illustrates a magnificent portrait of the presence of colonialism in post-colonial Samoa through one of the most tragical scene and the most victimized character, Siniva, Alofa's aunt, by the end of the novel: we are not living in Lightness" she would say. "We are not. Lightness is dead. Lightness died that first day in 1830 when the breakers of the sky entered these shores, forcing us all to forget... to forget... to burn our gods... to kill our gods... to re-define everything, recording history in reverse (Figiel,1996,P. 233)

One would immediately be completely alerted by what Siniva talks of. Reassuring that "breakers of the sky", not only invaded the land, but rather invaded Samoan peoples' mind "forcing" them "to forget". Colonizers penetrated deeply into Samoan culture, religion and peoples' value. The island of Samoa has been washed away from all of myths, their religion and gods making it very easy for one to conclude that the society has been Christianized. If one wanted to catch a liar in Samoa, one of the tricks they used was "If you can recite the twenty-three psalms backwards without taking a break then you have passed the test that you don't dream." (Figiel,1996,P. 45).Pastors were of highly respected position within the community and Samoan children get their religious education "at the fale o le faifeau" to learn to "read the Bible correctly". The point Siniva made about "burning our gods" was that people in Samoa were required to recite Bible "with meek and humble voices" (Figiel,1996,P. 137).Coming-ofage children were taught to "recite passages, to recite all the books of the Bible, from Creation to Revelation"(Figiel ,1996,P.137).Christianity, having replaced Samoan religion, was the present force and belief shaping everyday life in Samoa. Moreover, There are pillows with "Jesus is the reason" (Figiel,1996,P. 40).There were "Bibles practically everywhere" (Figiel,1996,P. 56).When Fisili AkuIai "tripped over the sack of Bibles and hymn books". "Everyone is blinded... Blinded by too many Bibles. Blinded by too many cathedrals." (Figiel,1996,P. 233)

It has been mentioned earlier that colonialism was a cultural control rather than being purely a power control (Ashcroft and et al). The same argument has been made by Edward Said as he puts it "the Orient needed first to be known, then invaded and possessed, then re-created by scholars, soldiers, and judges." (Said,1967,P. 92) The Samoan life is the product of careful analysis of missionaries and American scrutiny. Another evident is the presence of "Mr. Brown" in the novel indicates the very presence of colonialism and Western control over Samoan community for "Mr. Brown works for the Bank of Western Samoa" (Figiel,1996,P. 6).This leads one to assert that such presence would result in shocking consequences as Said states in "Orientalism" "In many ways my study of Orientalism has been an attempt to inventory the traces upon me, the Oriental subject, of the culture whose domination has been so powerful a factor in the life of all Orientals." (Said,1967,P. 92).

The effects of colonialism are obvious when Alofa, Moa and Lili are nosing around Mr. Brown's house they come across a magazine with nude pictures that causes the girls wrongdoings. It shows the impact of Mr. Brown, an emblem of the West, on the Samoan people. Alofa comes across a box of cornflakes. She is fascinated: "I had never seen cornflakes in real life. I'd always seen them on TV . . . Cornflakes made palagi [white] people happy. I wanted to see what it could do to Moa and me." (Figiel,1996,P. 9-10). Cornflakes become the emblem of a consumer desire fueled by the very presence of colonialism. These are evident why Siniva believes that Samoan people and culture are dying: 
Suicide - it is the only way. For isn't that what we're all slowly doing anyway? Each time a child cries for Coca-Cola instead of coconut-juice the waves close into our lungs. Each time we choose one car, two cars, three cars over canoes and our own feet, the waves close in further. Further and further each time we open supa-keli... pisupo... elegi instead of fishing nets... raising pigs... growing taro... plantations... taamu... breadfruit. Each time we prefer apples to mangoes... pears to mangoes... strawberries to mangoes. Each time we prefer tin and louvres to thatched roofs. Each time we order fast-fast food we hurry the waves into our lungs. We suffocate ourselves - suffocate our babies and our reefs with plastic diaper... formula milk... baby powder... bottled baby-food and a nuclear bomb, too, once in a while. Drowning our children with each mushroom cloud, Lobe Boat... Fantasy Island... Rambo... video game... polyester shoes, socks - everything polyester (Figiel,1996,P. 234)

Alofa, Moa and Lili identify themselves as "Charlie's Angels", an American Tv Show. As they "navigate the difficult dialectic between cultural consumption and cultural production--pretending to be Charlie's Angels, but also modifying the roles to suit their purposes. They illustrate the complex relationship between colonialism, commodification and sexuality." (Yamomto,2000,P. 384) Western culture seems to be imposing itself upon the Samoan life as Said states in "Orientalism" that "cultures have always been inclined to impose complete transformations on other cultures, receiving these other cultures not as they are but as, for the benefit of the receiver, they ought to be." (Said,1993,P. 67).

The question of identity in postcolonial novels is of vital significance in which the colonized, in this case Samoan people, are in conflict and struggle to find a way for the identification between previous native heritage, history and the dominant power of the colonizer imposed on the culture. This idea is discussed by Edward Said that the national re-establishment of society, affirmation of identity and the appearance of new cultural practices launched as mobilized force and then advanced the struggle against Western domination everywhere in non-European world (Said, 1967). It is 1972, and Siniva comes back from New Zealand, after receiving her bachelor's and master's degree in history, wearing "an afro, wore no bra... and you could easily see her nipples through the Jimmy Hendrix T-shirt she was wearing." (Figiel,1996,P. 185). Figiel through portraying the character of Sivia she smartly gives an analysis of the effects of Western capitalism and religious colonialism upon Samoa. As its clear in the novel that Siniva privileges the old religion of ancient Samoa, refuses to eat non-native and imported foods.

We kill ourselves slowly," she says. "Every day, every Sunday. Each prayer to Jesus means a nail in our own coffin. Each time we switch something ON (radio, lamps, TV, ignitions ...) means a nail in our coffin. And agaga [soul] as we once knew it dies in our still biologically functionable bodies, full of junk food ... darkness-food . . whitefood ... death food. (Figiel,1996,P. 238)

But Siniva is ignored and shushed by the community. She becomes blind and eventually commits suicide. While she can see what is happening to her community, she cannot see that the solution does not lie in clinging to a static dream of a pure past. This "attachment to traditional culture" shown by Siniva can be regarded, as Alberto Melucci puts it, as an "attempt to resist the dissolution of identity as an essence" (Melucci,1997,P. 65) . This is a sheer struggle to establish one's identity.

Furthermore, the title, Where We Once Belonged, refers not only to a place that has been taken by Christian missionaries and Western pop culture, but also references the ways in which the collective "we" is being steadily replaced by the singular "I." At school, where Miss Cunningham tries to get her students to write about the experiences of that individual "I," Alofa, puzzled as she was, resists. To her, to speak of a singular experience of the "I" is to be alone: "You were always with someone .... Nothing was witnessed alone. Nothing was witnessed in the 'I' form--nothing but penises and ghosts. 'I' does not exist, Miss Cunningham. 'I' is 'we' . .. always." (Figiel,1996,P. 133). One can easily see the atrocities that the Samoan people are faced with. They are ruled and the ruling power is there in the culture and everyday life by having distorted the history and the individuals' value and identity. Thus, it is fair to resort and agree with what Edward Said states in Culture and Imperialism that "they weren't like us for that reason deserved to be ruled."(Said, 1993.P. 33). 
Postcolonial writings, in third world countries and cultures, are to a great extent preoccupied with the status of women as the most significant issue. Therefore Holst-Peterson and Rutherford (1988) gave birth to a new term known as 'Double Colonization' which is still in existence over many years of age. It describes two forms of dominance, patriarchy and colonialism, even though they are comparable and overlapping. Postcolonial feminist writing inspects and scrutinizes women's role at the level of symbolism and also at the level of their functioning. Double colonization refers to women of colonized nations being doubly oppressed due to their race as well as their gender. It analyzes and dissects the issues of women as members of marginalized groups within postcolonial societies, the case of indigenous minorities, and as women with history of unbroken oppression. (Shenmugasundaram ,2017,P.389)

The whole nation being colonized and furthermore women within the same nation being subject at men's disposal "whose voices and actions have been muted, drastically reinterpreted, lost, or consciously swept away" (Nejat,2014,P. 1), The female characters experience double colonization due to their race and gender, and are therefore silenced. The double marginalization of the female characters is examined in this section. there are many instances throughout the novel one would undoubtedly encounter. Alofa, the protagonist, as a young girl full of hopes and dreams but she is always suppressed for she "knew the rules to Malaefou politics too well" so "when the lights went out I dies with them"(Figiel,1996,P. 15). One can clearly see how female voices were muted in a colonized community by the males of that community also by the authorial colonizers. The ready-made definition for females in the Samoan community requires girls to fit into it otherwise they are considered bad. Alofa states that "We were in-betweens... that is to say we were not completely good and we were not completely bad. To be in-betweens meant that we went to church: twice on Sundays and once during the fogo a kiakogo on Wednesdays" (Figiel,1996,P. 4)The girls spend their days and times and do "dullest of all chores", be it at home or church, to fit into the definition of being a good girl. The towering presence of both patriarchy and colonialism is what depicts the nature of "Double Colonization" in the novel for even from which Alofa is suffering when she says "what were we supposed to do to reverse the verdict that we were only in-betweens? And why was it so important for us [girls] to be 'good"" (Figiel,1996,P. $5)$.

Moreover, Lili is another female character who is doubly colonized. She is colonized by her father the one who raped her and by Mr Brown the representative of the colonial power in Samoan community. The patriarchal domination is very evident when she is raped by her incestuous father, Iosua. Only Alofa and Moa bother to engage into the truth about Lili's pregnancy, no one in the village cares to know the truth about it, which only contributes further to her image of a "bad girl" (Figiel,1996,P. 59).The girl is removed from school and Iosua continues his normal life. As well as $\mathrm{Mr}$ Brown practices his sexual desire on her when he tries to sleep with her more than one times, though she is too young for him. Mr. Brown loves "a lot with his fingers and tongue, not his penis" (Figiel ,1996,P.109) "His penis was dead. It lay there wrinkled like a rain-worm... all curled up... afraid of the sun" (Figiel,1996,P. 111).Although he cannot fulfill his sexual desire because he is too old, yet exploits her body by his hands and mouth. Furthermore, he leaves Samoa and Lili but writes to her from Australia inviting her to join him. Because in Samoan society Lili corresponds to the image of a bad girl, he wants to further humiliate her on his side as well.

The patriarchal power is practiced through the hypocritical character of Filiga, Alofa's father, in which he portrays behavior that does not get along well with what he preaches. Vaisola who was Filiga's first wife, out of too much degradation, because she failed to fit into the definition of a woman and to perform her primary duty, that is, to give birth to children, committed suicide. Logo, his second wife, with whom he has children, is suddenly sent back to her village without further discussion because, at whim, it turns out that Filiga has chosen a third wife, Pisa. Nevertheless, at the same time he is having an affair with Mrs.Samasoni, Alofa's teacher and they are seen together by the latter. All of these actions only demonstrate how women are significant to Filiga, symbolizing men in Samoa, only as a means by which to satisfy his sexual needs. Yet, he is the one who beats up Makaoleafi, Alofa's friend, and shaves her hair, when a pornographic magazine is found in her bag. In fact, whenever children need punishment, it is to Filiga, "the disciplinarian" (Figiel,1996,P. 213)that the villagers send them. Despite the whole community having been colonized by the colonizer, Filiga's character is indeed a confirmation of how "male-dominated, authoritarian and violent" (Mcleod ,1997,P.1) this culture is. Following these examples, one can conclude that Sia Figiel depicts a code of morality that is not the 
same for men or women. After having seen her father with her teacher, Alofa is free to behave the way she wants because Filiga refuses repeatedly to punish her. However, after she was caught naked with the village boy, Filiga violently beats Alofa. In her words she states:

before my hair was cut, before my hair was shaved, I was slapped in the face. Then a belt hit me across the face, too... around the waist, around my legs, around my face again. Fists blew in my eyes and mouth and cheeks, and blood flew out onto the cement floor. (...) I refused to cry any longer (...). This angered Filiga more and more, and he shouted that he was going to kill me. (...) Iopu and Filisi and Saufoi tore him away from my body. He was sweating... (...) his eyes not meeting mine... (...) As if I was the punisher and he the punished... (...) By beating me he was beating himself. (...) Beating Mrs Samasoni. Beating the memory of that (...) day when I saw him naked completely naked. And since then he was always naked in my eyes. (...) And he hated me for that (...) ...hated me for being like him" (Figiel,1996,P. 215-216).

In this manner, there is a connection between sexuality, guilt and violence that is plainly found in this passage. Although men are most of the time the seducers, it is always women who suffer the consequences that come mostly in the form of physical abuse. Everyone turns a blind eye on what Filiga and Iosua do as males. It proves the claim that women are doubly colonized. Even women who are supposedly innocent suffer abuse at the hands of men and, moreover, of other women. When Pisa moves into Filiga's fale, she is insulted by the second wife Logo and despite being taken in by the rest of the family, she is mocked, compared unfavorably to Logo and beaten repeatedly by Tausi, Filiga's mother. The fact that she gives birth to a baby girl is seen as a further punishment because "the curse of girls" is to "grow up to shame their "aiga" by continuing "the cycle of being seduced by middle-aged men" (Figiel,1996,P. 104).In order to break this cycle, she decides to bring Alofa up "ugly. [She] was never to know that [she] was beautiful. [She] was made to look ugly, [she] was dressed ugly, made to feel ugly" (Figiel,1996,P. 149).However, it is Filiga who seduces Pisa and takes her to the fale and it is him who lies: "He told her he wasn't married, didn't have a wife, didn't have children. (...) He swore it" (Figiel ,1996,P.103).It is also Mrs. Samasoni who is assaulted by Pisa when she discovers that she has a son by Filiga and, once again, Filiga escapes with immunity.

Additionally, Filiga and other men are not accused of exaggerated beatings or muting and suppressing females' voices in a colonized society. The chapter "Real Love" included by Sia Figiel in the novel further evidences this. Here she states through the voice of Alofa that "being beaten up is alofa - love". "Real love is when children are beaten up bad by their parents. (...) To beat a child is to give her respect, to teach her how to behave, to teach her to be humble, to listen, to obey, to love her" (Figiel,1996,P. 219).One must notice the use of the pronoun "her" to further support the idea that women are, indeed, doubly colonized.

The previous section was concerned with the concept of 'Double Colonization' which inherently in itself involves the persecution of women rights and violence against them as a distinct gender in a colonized community. This section, however, will be concerned with the actual acts of violence against women and their rights being persecuted. Reading the novel, one would, with all certainty, encounter many instances of such acts. Almost all the female characters are persecuted by the male counter partners. Figiel presents the reader with Alofa's constant fear of failing to be a "good girl" or at least an "in-between" for she states "I knew the rules to Malaefou too well" keeping in mind an incident happened earlier when" Sila, a girl of fourteen, called Fa'avevesi's mother a whore who was screwing all the aumaga of Malaefou, war was raged and Sila's mother was taken to Motootua Hospital. She couldn't see straight for days" (Figiel,1996,P. 15).Thus, Alofa is obsessed with a question in her mind that why "people see surfaces only" (Figiel,1996,P. 15).especially in case of women and girls and the clothes they wear or things they do.

Women in Where We Once Belonged live in a society where female chastity and virginity is strictly enforced and not in her own control. Diametrically opposed to Mead's claims for sexual freedom which are explained to Alofa by another girl as "Mead was a palagi [white] woman who wrote a book on Samoan girls doing 'it' a lot... they were loving and loved 'it' too" (Figiel,1996,P. 204).Figiel's narratives emphasize the fact that Western Samoan girls are expected to be chaste, diligent, clean and religious. For instance, Alofa's frustration is often expressed at the importance put upon maintaining a 
respectable public image, a "good girl". She and her friends are irritated by the fact that a bullying girl named Makaoleafi is venerated by the adults of Malaefou because she presents a façade, an appearance, of accomplished virtuosity in public while misbehaving with impunity in secret. However, the inherent crumbliness of public respectability is shown in an episode where Alofa's friend Moa plants a pornographic magazine, stolen from Mr Brown in Afi's schoolbag. After the magazine is found, Afi falls from her grace immediately and she is beaten so severe that she is forced to remain home from school for two days while her wounds heal. When she returns into the society, her hair is shaved in order to draw further public attention to her humiliation.

Moreover, one would, for sure, reaches a conclusion that experiments with sexuality are the worst possible offences a female can commit in this Samoan community. Alofa herself, for example, is caught at the beach, engaged in the act of her first sexual experience with Lealofi, the pastor's son. Her father, Filiga, beats her so brutally that the wounds on her face take two weeks to heal and then she, too, is sent to school with shaved head as an advertisement of her 'shave' (Keown,2004,P. 100). Figiel builds a code of morality regulated by a sexual double standard. For example, Alofa prior to her own sexual encounter stumbles upon her father having sex with her schoolteacher, Mrs Samasoni, and the retaliatory violence which follows after Alofa's 'affair is discovered is represented as a form of reverse punishment for her father's adultery:

Filiga ... shouted that he was going to kill me... ... lopu and Filisi and Saufoi tore him away from my body. He was sweating ... his eyes red like fire ... his eyes not meeting mine ... afraid, somehow, to meet mine. As if I was the punisher and he the punished ... and he knew it ... and I knew it. ... By beating me he was beating himself. ... . Beating Mrs Samasoni. Beating the memory of that bridge-umbrella rainy day when I saw him naked - completely naked. ... . Filiga . hated me for being like him.

(Figiel,1996,P. 215-16).

Despite verbally abusing the schoolteacher, it is Alofa who eventually pays the price "for being like him" when she is caught doing the same thing her father did. Figiel, here, shows the relationship between gender, sexuality and violence, analyzing more closely the negative effects of sexual degradation upon the female psyche. Her stories are full of episodes where men seduce or force women and girls into performing sexual acts. While men are the instigators, it is usually the women who suffer the physical and psychological consequences of these actions, whether they take the form of beatings, exclusion or unwanted pregnancies.

Furthermore, Figiel presents a recurring theme of abuse and mistreatment towards women throughout Where We Once Belonged focusing in particular upon Alofa's family. Another example for women persecution is Alofa's mother Pisa, her life mistake was when she falls pregnant to Filiga, unaware of the fact that he is still married to his second wife Logo. Filiga subsequently sends Logo out of the house without warning in order to make way for Pisa and the new baby, and Logo's despair and anger are directed not at Filiga who knowingly instigated the extra-marital affair, but rather at Pisa, who, when she fell pregnant, was completely unaware that Filiga already had a wife and children. The newly established Pisa is mocked and beaten by Filiga's female relatives especially Filiga's mother Tausi and she is constantly and unfavorably measured against the ousted Logo. The gender of her child is viewed as further grounds for mistreatment, and Pisa herself believes she is "cursed, just like her mother, to bear girls" (Figiel,1996,P. 104). As a part of a strong patriarchy system in Samoa, Alofa's family story suggests that Western Samoan women are part of their own oppression, as Pisa is made to suffer particularly at the hands of her new female in-laws for Filiga's sexual transgressions. Moreover, instead of feeling pity for her illegitimate daughter, Pisa uses Alofa as a scapegoat for her own misery, bringing her up to believe she is "ugly" (Figiel,1996,P. 149).

Likewise, Siniva, Alofa's aunt ,is another character in this novel, whom is she persecuted by the society. The Samoan community is diseased by Prejudgment, in which it is always the way to deem anyone's personality or act who does not conform to the social, however patriarchal, norms and it is usually based on the appearance of the people, specifically females. The most notable instance of such judgment and women right persecution can be clearly seen in the case of Siniva. After returning from New Zealand and seeing what an ordinary Samoan cannot see they deemed her the town-idiot, "She looked like a hippie. She looked like a real bum in the eyes of everyone when she stepped out of the airplane at Faleolo. 'What have you done to yourself?' the women asked. 'What have you done to our 
Siniva?(Figiel ,1996,P.191).When in reality, she was the most aware of what was happening to her home and only wanted to help the village. She would preach to her family and other people of the town what they could not comprehend. (Kaya,1999,P. 100). She was secluded, degraded, disrespected and persecuted which all led to her suicide and even then "the village of Malaefou does not weep and the village of Malaefou does not mourn... it continues as if Siniva never existed" (Figiel,1996,P. 233).

In addition to Siniva, Alofa, and Pisa , there is also the smartest girl in the village named Filifili is impregnated and becomes mentally ill after being forced into having an abortion. She too was pressured into sex by a young local boy. Instead of accusing the boy or forcing him into marriage, her family anxious to avoid a scandal, invents a more satisfactory reason for the illness, conveniently deeming her insane rather than addressing the youth himself. Filifili's is not the only example, Lili's case who is raped by his incestuous father, Iosua. Only Alofa and Moa bother to engage into the truth about Lili's pregnancy, no one in the village cares to know the truth about it. The girl is removed from school and Iosua continues his normal life.

In Figiel's novel therefore, the women continue the recurring pattern which bell hooks describes in her analysis of domestic violence in Afro-American/black communities. She analyzes female violence, both against other women and against children, as a consequence of "community acceptance of male violence against women", arguing that the "deeply internalized pain and self-rejection" which results from male abuse "informs the aggression inflicted on the mirror image - other black women" (Hooks,1999,P. 42). In Where We Once Belonged, Alofa's family is represented as a microcosm for a wider community which functions precisely in these terms. Alofa's account suggests that transgressive women who fail in their domestic tasks or challenge patriarchal authority or derail from the line drawn for women by men are constantly beaten, chastised and excluded.

The Samoan women having been doubly colonized and their rights being persecuted and their existence undignified, a reader equipped with thorough understanding of postcolonial era would see resistance, inherent to postcolonial nature itself, which is worth discussing. Women actually in many instances resist the violence, persecution, double colonization and the efforts made to suppress their voices. Alphonso Lingis argues that "bodies that are forcibly subjected produce power in their turn" given that they "devise their evasions, resistances, ambushes, ruses, and mockeries" (Lingis,1999,P. 286). There are two female characters in this novel that resist the patriarchal and colonial powers.

Alofa, the young girl, who is always in possession of the fighting spirit to the Colonized Samoa and subjugation. Alofa was always different from other female characters, she describes herself and her friends as "in-betweens" and she further explains that "we were not completely good and we were not completely bad" (Figiel,1996,P. 4).and despite their attempts at "good" things, such as never missing church meetings, doing chores for the pastor, helping their mothers cook and clean, "We were in-betweens because we loved laughing, and laughed and laughed at the slightest things" (5). Laughing is viewed as a dangerous and subversive activity because laughing inherently disturbs order and silence. (Solar,2010,P. 20).

In contemplating about her future, she makes her own resolution that "I'm never gonna be like Pisa when I grow up. I'm never gonna be like Fiakagaka when I grow up. I'll never even look at men. Men don't exist. They won ' $t$ " (Figiel,1996,P. 149).Alofa, is the only one to go on a journey on a new, unexplored path. A frightening one, perhaps, but it is also one that demonstrates her courage. The "Tuli of Tomorrow" seems to promise a brighter future, one that successfully combines Samoa symbolized through the tattooing of the fue and the to'oto'o which "represents a hierarchy that has not yet fallen into Western standards of hypermasculinity" (Solar,1967,P. 13). combined with Alofa's deliberate walking away from the gravesite but there is still a hint of regret in the last three words of the text which, at the same time, signifies a disabling fracture from the past. Alofa's position as a teen girl, as well as her own specific experiences and knowledge, places her in an uncertain position between the dangers that "home" and "tradition" can represent as well as the frightening future forecast by her Siniva's suicide. Alofa states:

before my hair was cut, before my hair was shaved, I was slapped in the face. Then a belt hit me across the face, too... around the waist, around my legs, around my face again. Fists blew in my eyes and mouth and cheeks, and blood flew out onto the cement floor....I refused to cry any longer .... This angered Filiga more and more, and he shouted that he was going to kill me.... Iopu and Filisi and Saufoi tore him away from 
my body. He was sweating... ... his eyes not meeting mine... ... As if I was the punisher and he the punished...... By beating me he was beating himself. ... Beating Mrs Samasoni. Beating the memory of that ... day when I saw him naked - completely naked. And since then he was always naked in my eyes. ... And he hated me for that ......hated me for being like him. (Figiel ,1996,P.215-16).

After having been caught with a village boy, Alofa is expected to get her punishment. One can see she is puzzled as to why she would have to face punishment for something that her father has done before him. Alofa had seen an episode of her father, Filiga, engaged into intercourse with her teacher Mrs.Samasoni. Now poor Alofa has to suffer but she decides to be brave, she "refuses to cry" which is pure resistance to the inequality and nonsensical male-dominant system of life. The resistance angers Filiga so much. He cannot even look at Alofa in the eyes. That is what happens to men when women decide to resist in the Samoan community.

Likewise, Alofa 's aunt, Siniva, also symbolizes resistance. Her tragic case consists of so many aspects worth scrutinizing; one being resistant to submit to the Samoan mentality. Although she ends up with suicide but one cannot avoid symbolizing her as the symbol of resistance in the novel. Alberto Melucci in describing Siniva's ideology shows it as an "attempt to resist the dissolution of identity as an essence" (Melucci,1997,P. 19). The concluding lines in Where We Once Belonged, Siniva leaves a burden of responsibility to Alofa through the final lines of her suicide note . (Henderson ,2016,P.20).

But tell me this once, my little dreamer, did I have a choice? Do you have a choice now that your own eyes are opened to the darkness?"' Reflecting on the message, Alofa reaches a moment of seemingly un-Samoan existential resolution: "After reading Siniva's thought, I am silenced. Alone. For the first time I am alone. I am 'I' in its totality — 'I' without 'we' . . without Moa, Lili, girls, boys . . . I am (Figiel,1996,P .235-36).

Alofa is now faced with an idea, a possibility that there might be truth in Siniva's observations, Alofa contemplates whether she should commit suicide like Siniva, as so many other people are said to have done in the book and so many Samoan young people do in reality, outside of the world of Figiel's fiction (Macpherson,1987,P. 19). But Alofa does not choose this path:

As I thought these thoughts the Tuli of Tomorrow flew high up in the sky, a fue tattooed on her wings, a to 'oto'o tattooed on her peak. The Tuli called to me, her voice music to my feet, and I began walking . . w walking-walking . . . away from Siniva's grave . . . walking now towards Malaefou, towards the new gathering place where 'we' once belonged (Figiel,1996,P. 236).

\section{RESULTS}

The selected novel has been examined through postcolonial feminist lens. The concept of double colonization is discussed by applying Edward Said's theory of Orientalism, by considering the other in Said's term to all women in postcolonial societies. Thus, women in these countries, are colonized twice, they also resist both the colonial and patriarchal powers.

\section{CONCLUSION}

Based on Edward Said's theory of orientalism, the theoretical framework of the paper demonstrates how the European other is the other silenced female character according to postcolonial feminism. Female characters suffer both patriarchy and colonial domination. The novel is a form of "writing back" and Figiel does double duty by describing the narrow confines of the world of women who are constrained because of gender as well as ethnicity. Figiel also takes to task typical Western notions of individuality and identity through her portrayals of women, community and subjectivity. She explores movement and emplacement particularly through her imagining the various centers available to the imagination. The recurring pattern in Figiel's work is the notion of multiplicity in the sense that Lowe describes, "designating the ways in which subjects located within social relations are determined by several different axes of power" (1995) but also in the sense of having multiple possibilities. Figiel's 
main narrator, Alofa, constantly wonders about the multi-layered facets of people and places and states that "people see surface only, and that is all. They don't care to look under tables, or mats, or in a book, or bite afruit" (Figiel ,1996,P.15). She comes to a deeper and more sympathetic understanding of her family and friends, especially for her lost Siniva . Finally, this novel is very important in educational fields. The language of the novel helps foreigners to improve their English language and practice it. Further it helps the students to think in English while discussing it in class. Most importantly, the novel provides students of postcolonial literature and feminism to better understand the context of postcolonial.

\section{REFERENCES}

Ashcroft, B. 1989. Gareth Griffiths, and Helen Tiffin. The Empire Writes Back: Theory and Practice in Postcolonial Literatures. London: Routledge.

Brown, T. 2015. "Book Review - Free Love”, Te Kaharoa, 8(1). doi: 10.24135/tekaharoa.v8i1.35.

Bulbeck, C. 1998. Re-orienting western feminisms: women's diversity in a postcolonial world. Cambridge New York: Cambridge University Press.

Crane , M . 2004. The Political Junkie Handbook. Publisher: S.P.I. Books.

Figiel, S. 1996. Where We Once Belonged . London : Penguin group.

Guerin et al. 2005. in A Hand Book Of Critical Approaches To Literature.

Henderson, K. 2016. April The I and the We: Individuality, Collectivity, and Samoan Artistic Responses to Cultural Change. University of Hawai'i Press.

Holst,P Kirsten \& Anna, R .(1988).Double Colonization: Colonial and Post-Colonial Women's Writing. Inland Book Company.

Hooks, b. 1999. Black Looks and Race and Representation, South End Press Boston, Kaya Press.

Keown, M. 2004. Postcolonial Pacific Writing: Representations of The Body, London: Routledge.

Lingis, A. 1999. "The Subjectification of the Body" In The Body, Ed. Donn Welton. Malden, Massachusetts: Blackwell Publishers Ltd .

Lowe, L. 1997. Immigrant Acts: On Asian American Cultural Politics. Durham: Duke UP.

Macpherson, C\&La'avasa, M. (1987). Towards an Explanation of Recent Trends in Suicide in Western Samoa. Man 22 (2 [June]): 305-330.

McLeod, A. 1997. "The most exciting recent book" In New Zealand Books, 7:2, June 1997: 1/5.

Melucci, A. 1979. Identity and Difference in a Globalized World In Debating Cultural Hybridity, Eds. Pnina Werbner and Tariq Modood. London: Zed Books .

Melucci, A. 1997. "Identity and Difference in a Globalized World" In Debating Cultural Hybridity, Eds. Pnina Werbner and Tariq Modood. London: Zed Books 58 - 69.

Nejat, J. 2014. "Double Colonization in John Maxwell Coetzee's Disgrace" 2014 JNAS Journal-20143-1/40-44.

Said,E . 1967.Orientalism. New York: Vintage Books.

Said,E. 1993. Culture and Imperialism. London: Chatto and Windus.

Shenmugasundaram,Y. 2017. POSTCOLONIAL FEMINISM.

Solar, V. 2010. Imagined Islands: American Empire and Identity in the Postcolonial Pacific. Doctor of Philosophy. UNIVERSITY OF CALIFORNIA RIVERSIDE.

Yamomto, T. 2000. Journal of Asian American Studies: Volume 3, Number 3. Johns Hopkins University Press. 